\title{
Research on Control of Distributed Wind Solar Hybrid Power System
}

\author{
Qing Wang ${ }^{1, *}$, Yan Qin ${ }^{1}$, and TianYing $\mathrm{Li}^{1}$ \\ ${ }^{1}$ School of electrical \& energy engineering, Nantong Institute of Technology, China
}

\begin{abstract}
In this paper, the authors proposed control strategy algorithm(i.e.,maximum power point tracking(MPPT)) to improve the maximum power generation efficiency of distributed wind and solar power generation.The control algorithm mainly adopted the perturbation observation method(i.e., Power, Current, Torque, Speed and other parameters were perturbed, and the control value was adjusted according to the change of output value, so that the output value finally tended to the given value) and the improved MPPT control algorithm(i.e., change the reference voltage to change the duty ratio).Finally, the authors showed that the efficiency of electricity generation was significantly improved by experimental data comparison.
\end{abstract}

\section{Introduction}

Energy is the foundation of survival and development of human society, with the rapid development of modern industry, the traditional energy consumption caused excessive development, ecological environment deterioration and global warming. The problem forced mankind into a new stage of energy utilization.

In terms of the current maturity of new energy development, wind and solar energy were the most widely used renewable clean energy sources with high technology.In order to solve the randomness of the wind power and solar energy intermittent, the natural hybrid of the wind and solar was utilized in the power generation system, combined each other, and made the most of natural resources to provide stable and sufficient power.

Distributed generation systems were independent of each other, and when an accident occured in a power station, there would be no power failure on a large scale. Therefore, safety and reliability were higher than centralized power supply. Of course, distributed generation systems as an important supplementary part of the large power grid, when unexpected disasters occured, it could make up for the instability of the large power grid and continue to provide power to users. Distributed generation systems were suitable for rural, pastoral areas, mountains, and small range of commercial and residential area power supply ${ }^{[1]}$. Distributed generation system had some very good features, such as low loss of power transmission and distribution and did not need to set up sub-station, greatly reduce the cost, the load performance very good, simple operation, start-stop faster and regional power quality monitoring. Most distributed wind and solar hybrid system on the market just simple combination design was made for the wind turbines and solar panels, although they solved the complementarity of natural resources to some extent, but the lack of a more rigorous scientific control strategy, system efficiency was not high. At the same time, due to both the randomness and intermittent of natural resources, the power was not stable, and had a certain impact on the grid. In this paper, according to the current wind speed and lighting information, the authors calculated the maximum power reference value of the system, constructed mathematical model according to the output power of the actual system, used the control algorithm to coordinate the control of the system, so that the running state of the system could reach the ideal target.

Microgrid was a low-voltage system composed of distributed power supply, energy storage and load. It took a group of distributed power supply, loaded as a cluster partition network and given full play to the efficiency of distributed power supply through reasonable control and management. In recent years, the state had also provided relevant supporting policies to micro grid, especially the guidance on promoting the construction of new energy micro grid demonstration projects issued by the state energy administration in 2015, which had made the technology of micro grid more widely used in the market. Due to the fluctuation of wind energy and solar energy and the variability of load, the stability and reliability of micro grid would be seriously affected in distributed wind and solar hybrid power system. Therefore, it was necessary to reasonably configure the micro grid to meet the flexible cooperative control safe and efficient operation of the micro grid.

\section{MPPT control strategy}

\subsection{Wind power generation system}

* Corresponding author: qingwang2012@126.com 
The control method of MPPT was widely used in wind power generation system, such as discrete iteration control method, wind speed automatic tracking control method and wind turbine speed feedback control method etc. The power signal feedback control method was used to find the maximum power point through wind turbine maximum power curve. This method did not need to increase the wind control device, which could allow the wind turbine to be in the best state of automatic tracking, but the tracking speed and accuracy could not be both. Wind speed automatic tracking control method required wind. The wind device collected wind speed signal in real time, through the comparison of the theory and the actual power, the output power of the wind generator was adjusted by calculation and analysis, this method energy conversion efficiency was higher. Wind speed feedback control method was similar to the control process of wind speed automatic tracking control method, and the previous method was to adjust the control by gathering the wind speed signal ${ }^{[2-3]}$ and the method was to collect the power signal control, so this method was more reliable.

This paper made an improvement on the basis of the research on the speed feedback control method of wind turbines and put forward an optimized MPPT control method to improve the efficiency of the power generation facilities of the main hybrid power generation system.

In order to overcome the power signal feedback control method shortcoming, the authors proposed the MPPT disturbance of wind power generation system, which did not need measure wind speed and predicted the power characteristic curve of wind turbine. Also known as mountain climbing or search method, perturbation method to power, current, torque, speed and other parameters were perturbed and the control value was adjusted according to the change of output value, so that the output value finally tended to the given value. The implementation process of the method was as following, the artificially imposed disturbance variation speed, according to the characteristics of the generator output power of control wind turbine speed adjustment value, control the generator electromagnetic torque wind turbine speed had been given, repeatedly performs the disturbance in the adjustment process, eventually making the maximum power point of wind power system was run. Due to a certain speed, the speed of the wind turbine in a power curve was in the shape of class parabolic, the search method controlled the operation point of the wind power system in parabola by changing the wind turbine speed continuously and then automatically searched the optimal speed to generator. According to the search step length used in the control ${ }^{[4]}$, the method included fixed step search method and variable step search method. For large wind power systems, because of the large time constant, the wind turbine had a large moment of inertia, there was a certain deviation in this method for real-time control of the maximum power point of the large wind power system. The disturbance observation method was shown in figure 1.

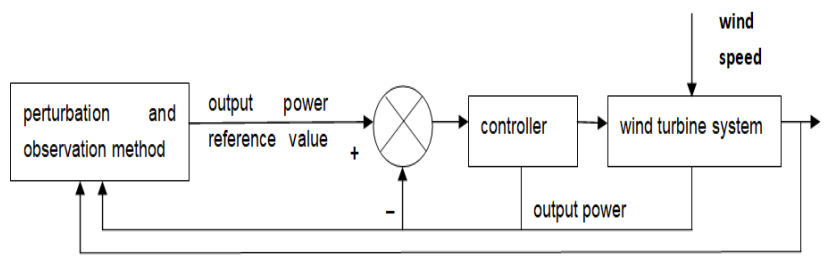

Fig. 1. Perturbation and Observation method diagram In general, this method was simple in principle, simple in control and low in cost. It did not need to discuss the relevant parameters of wind turbine and motor in detail and was easy to implement. However, In order to carry out the forward and backward conversion comparison of output power value. The control signal must be artificially disturbed.

\subsection{Solar power generation system}

The solar cells panel worked in certain circumstances only one Point of maximum Power output (Max Power Point, the MPP for short), and the maximum Power output Point varied with the running environment.

In practice, the irradiation of sunlight intensity and atmospheric transmittance moment would fluctuate, in order to convert solar energy into electricity as much as possible. To output maximum power point tracking became the key technology of solar power generation at any time.

The MPPT control methods used in solar power generation facilities mainly include disturbance measurement method, conductance increment method and fuzzy control method. The working process of the perturbation measurement method was relatively simple. When the environmental conditions had not changed, this method could judge which direction the maximum power point was in by the change of the working voltage of the battery components, so as to determine the maximum power point of the battery components through repeated comparison ${ }^{[5]}$. However, when the environment changed, this method would be misjudged. The incremental conductance method was used to determine the position of the maximum power point by comparing the conductance and the conductance of the battery components, which was more accurate than the perturbation measurement method. If the voltage increment was increased in order to improve the tracking speed, the shock would occur near the maximum power point. Therefore, two working areas needed to be set in practical application.In MPPT control, the fuzzy control method could make solar cell components to adapt the weather quickly. However, this method needed to be based on the set fuzzy control table, which had certain defects and could not be completely accurate. In addition to the MPPT method, there were many other methods, each of which had its own unique characteristics. In this paper, the perturbation measurement method and the incremental conductance method were reformed and optimized, so as to realize the MPPT control of solar power generation facilities in the wind and solar hybrid power generation system. 
In this paper, the improved MPPT control method(that is, Direct-crrent/direct-current/ $\Delta$ Duty-ratio algorithm, $\mathrm{D} / \mathrm{D} / \Delta \mathrm{D}$ for short) was used to realize MPPT. The $\mathrm{D} / \mathrm{D} / \Delta \mathrm{D}$ control method was used to realize the MPPT control of solar power generation facilities. This method changed the duty ratio by changing the reference voltage $\mathrm{U}_{\text {ref }}$ expression.

$$
D_{K}=D_{K-1}+\Delta D
$$

In equation (1), $D_{k}$ and $D_{k-1}$ are respectively occupied at the moment $\mathrm{k}$ and $\mathrm{k}-1 \mathrm{empty}$ ratio, $\Delta \mathrm{D}$ for duty ratio increment. $\Delta \mathrm{D}$ more critical values, simple method was that $\Delta \mathrm{D}$ took a fixed value, but a fixed value was too large, easy to cause shock near the maximum power point, obtaining and reducing its speed was too small.So, $\Delta \mathrm{D}$ still needed to take a variable, its calculation model was as follows, The output power of the solar power generation facility expression.

$$
P_{P V}=\frac{U^{2} P V}{R_{P V}}
$$

In equation (2), $\mathrm{P}_{\mathrm{PV}}$ is the output power of solar cell components. The $\mathrm{U}_{\mathrm{PV}}$ is the output voltage of the solar cell module. $R_{\mathrm{PV}}$ is the equivalent resistance of the output port of the solar cell module.

Buck circuit, for example, the output of the solar energy battery components electrical pressure load expression.

$$
U_{O}=D U_{P V}
$$

Efficiency expression

$$
\eta=\frac{U_{O} I_{O}}{U_{P V} I_{P V}}=\frac{U_{O} I_{O}}{U^{2}{ }_{P V} / R_{P V}}
$$

In equation (15), $\mathrm{U} 0$ is the load voltage, I0 is the load current.

load resistance expression

$$
R_{1}=U_{O} / I_{O}
$$

It could be obtained from equations (3), (4) and (5)

$$
R_{P V}=\eta R_{l} / D^{2}
$$

The output power of the photovoltaic power generation facility was obtained.

$$
P_{P V}=\frac{U^{2}{ }_{P V}}{R_{P V}}=\frac{U^{2}{ }_{P V} D^{2}}{\eta R_{l}}
$$

It could be seen from equation (7) that $\mathrm{P}_{\mathrm{PV}}$ is proportional to $U_{\mathrm{PV}}$ and $\mathrm{D}$. For the convenience of derivation, equation (7) was simplified.

$$
P_{P V}=U_{P V} D
$$

The derivative of equation (9) was obtained.

$$
\frac{\partial P_{P V}}{\partial D}=U_{P V} \frac{\partial}{\partial D} D+D \frac{\partial}{\partial D} U_{P V}
$$

The rate of variation of output power of components was not a fixed value. In order to reflect the adaptability of system performance, $\Delta \mathrm{D}$ also needed to be set as a variable and its variation rules.

$$
\Delta D=K \frac{\partial P_{P V}}{\partial D}
$$

In equation (10), the value of coefficient $\mathrm{K}$ is automatically set at the initial stage according to the initial state.

$$
K=\left|\frac{\Delta D}{\partial P_{P V 0} / \partial D_{0}}\right|
$$

$\mathrm{D} / \mathrm{D} / \Delta \mathrm{D}$ control method could automatically set according to the system current status to adapt to the step of the operation of the system to minus the irrationality of artificial settings, enhanced the accuracy of maximum power point tracking and sensitivity.

\begin{tabular}{|c|c|c|c|}
\hline $\begin{array}{l}\text { weather } \\
\text { conditions }\end{array}$ & $\begin{array}{c}\text { state of } \\
\text { calculation of } \\
\text { power }\end{array}$ & $\begin{array}{l}\text { Wind } \\
\text { power }\end{array}$ & $\begin{array}{l}\text { Solar } \\
\text { power }\end{array}$ \\
\hline \multirow{2}{*}{$\begin{array}{l}\text { wind and solar } \\
\text { sufficient }\end{array}$} & $\begin{array}{c}\text { Pwind }+ \text { Psolar- } \\
\text { Pload }<0\end{array}$ & $\begin{array}{l}\text { Maximum } \\
\text { power } \\
\text { tracking } \\
\text { control }\end{array}$ & $\begin{array}{l}\text { Maximum } \\
\text { power } \\
\text { tracking } \\
\text { control }\end{array}$ \\
\hline & $\begin{array}{l}\text { Pwind }+ \text { Psolar- } \\
\text { Pload }>0\end{array}$ & $\begin{array}{l}\text { Load power } \\
\text { tracking } \\
\text { scenery } \\
\text { coordinatio } \\
\text { n control }\end{array}$ & $\begin{array}{c}\text { Load } \\
\text { power } \\
\text { tracking } \\
\text { scenery } \\
\text { coordinatio } \\
\text { n control } \\
\end{array}$ \\
\hline \multirow{2}{*}{$\begin{array}{c}\text { Wind sufficient } \\
\text { Solar } \\
\text { insufficient }\end{array}$} & Pwind-Pload $<0$ & $\begin{array}{l}\text { Maximum } \\
\text { power } \\
\text { tracking } \\
\text { control } \\
\end{array}$ & stop \\
\hline & Pwind-Pload $>0$ & $\begin{array}{l}\text { Maximum } \\
\text { power } \\
\text { tracking } \\
\text { control } \\
\end{array}$ & stop \\
\hline \multirow{2}{*}{$\begin{array}{c}\text { Wind } \\
\text { insufficient } \\
\text { Solar sufficient }\end{array}$} & Psolar-Pload $<0$ & stop & $\begin{array}{l}\text { Maximum } \\
\text { power } \\
\text { tracking } \\
\text { control } \\
\end{array}$ \\
\hline & Psolar-Pload $>0$ & stop & $\begin{array}{c}\text { Maximum } \\
\text { power } \\
\text { tracking } \\
\text { control } \\
\end{array}$ \\
\hline $\begin{array}{l}\text { wind and solar } \\
\text { insufficient }\end{array}$ & $\begin{array}{c}\text { Pwind }+ \text { Psolar- } \\
\text { Pload }<0\end{array}$ & stop & stop \\
\hline
\end{tabular}

\section{MPPT control experiment}

\subsection{Wind power generation experiment}

The authors selected a wind scale in this region more normal day, according to the weather forecast as shown in table 1, conducted experiments on wind power generation. For tracking of the output power of wind power generation facilities, the authors recorded various situations as shown in table 2 .

Table 1. Operating state of system under different weather conditions

Table 2. Wind power generation equipment output power

\begin{tabular}{|c|c|c|c|c|c|c|c|c|c|c|}
\hline Point-in-time & $\mathbf{1 1}$ & $\mathbf{1 2}$ & $\mathbf{1 3}$ & $\mathbf{1 4}$ & $\mathbf{1 5}$ & $\mathbf{1 6}$ & $\mathbf{1 7}$ & $\mathbf{1 8}$ & $\mathbf{1 9}$ & $\mathbf{2 0}$ \\
\hline $\begin{array}{c}\text { Output } \\
\text { power(Perturbation and } \\
\text { Observation method) }\end{array}$ & 36 & 59 & 50 & 49 & 78 & 86 & 86 & 95 & 72 & 78 \\
\hline $\begin{array}{c}\text { Output power(No MPPT } \\
\text { control) }\end{array}$ & 28 & 52 & 44 & 37 & 70 & 80 & 81 & 89 & 59 & 70 \\
\hline
\end{tabular}




\subsection{Solar power generation experiment}

The authors selected a time period with sufficient sunlight to continuously track the output power of the solar power generation facility, conducted solar power generation experiment. The authors recorded various situations as shown in table 3 .

Table3. Solar power generation equipment output power

\begin{tabular}{|c|c|c|c|c|c|c|c|c|c|c|}
\hline Point-in-time & 6 & 7 & 8 & 9 & 10 & 11 & 12 & 13 & 14 & 15 \\
\hline $\begin{array}{c}\text { Output } \\
\text { power(D/D/ } /\end{array} \Delta_{\mathrm{D})}$ & 13 & 26 & 27 & 29 & 28 & 40 & 47 & 38 & 29 & 19 \\
\hline $\begin{array}{l}\text { Output power(No } \\
\text { MPPT control) } \\
\end{array}$ & 8 & 22 & 24 & 25 & 24 & 37 & 37 & 33 & 24 & 13 \\
\hline
\end{tabular}

Output power not controlled by MPPT was also recorded in table 2 and table 3 . The experimental data showed that the MPPT control system adopted in this paper. It could find the maximum power point of the system more quickly and in the same conditions of the output power was higher than without the MPPT control of power systems ${ }^{[6]}$.At the same time, these two control methods could also quickly capture the environmental changes and make the output power of the whole system stable at the maximum power point.

\section{Conclusion}

In this paper, the authors adopted above control technique that the system parameters were collected and analyzed in real time. Through these three technologies(that is, the analysis of various possible working modes, choose the best way to work and combined with the maximum power tracking technology), the system could generate the highest energy and keep the power grid stable. These methods could greatly improve the efficiency and quality of power grid when it was applied to large-scale distributed wind and solar energy hybrid power generation projects. From the perspective of social and economic benefits, it has high practical value.

About the author: Wang Qing, male, senior engineer, research interests and direction: new energy power generation technology and electrical engineering intelligent technology.

\section{Acknowledgment}

This paper is supported by NanTong Science and Technology Bureau fund of JiangSu Province (Grant No. GY12016044) and NanTong Institute of Technology fund (Grant No. 2017001).

\section{References}

1. Haihua ZHOU,BHATTACHARYA T. Composite energy storage system involving battery and ultracapacitor with dynamic energy management in microgrid application. IEEE Trans on Power Electronics,26,923(2011).
2. Xiaolin Liu.Wind Power.Solar Energy.1082(2009)

3. Karlic A.D..MPPT Method for PV System.Electric Power Systems Research.975(2009)

4. Mummadi Uezato.Feed forward MPPT of Power System.IEEE Transactions on Aero space and Electronic Systems.6,102(2010).

5. Yue Tan,Guanzheng Tan,Shuguang Deng.Hybrid particle swarm optimiztion with chaotic search for solving integer and mixed integer programming problems.journal of Central South University of Technology,21,2731(2014)

6. Pierluigi S,Costantino C.Designing fuzzy logic controllers for DC-DC converters using multiobjective particle swarm optimization. Electric Power Systems Research,112,74(2014) 